\title{
Strategi Diplomasi Ekonomi Indonesia dalam Menjaga Stabilitas Neraca Perdagangan di Tengah Pandemi Covid-19
}

\section{Natsha Nabilla ${ }^{1}$}

natshanabilla@gmail.com

${ }^{1}$ Departemen Ilmu Hubungan Internasional, Universitas Indonesia

DOI: $10.22219 /$ sospol.v7i2.15925

\begin{abstract}
Since first appearing in the city of Wuhan, China, COVID 19 has been declared by the World Health Organization (WHO) as a world health emergency. For Indonesia, COVID 19 pandemic has caused the trade balance deficit to 344.7 million USD as of April 2020. This situation has made Indonesia need a new strategy in maintaining trade traffic flows both domestically and internationally. This paper will discuss a new strategy in Indonesia's economic diplomacy as an instrument to increase international trade and investment. This paper will also limit the research during President Joko Widodo's administration both before and during the COVID-19 pandemic. Furthermore, in the discussion, we will use the concept of strategic diplomacy strategies for developing countries by Kishan S. Rana. Based on the research, it was found that some of Indonesia's strategies before COVID 19 started experiencing difficulties to increase trade balance. As a result, Indonesia started to adopt a new strategy that was in line with the conditions at the time of the COVID 19 pandemic. Even so, in general, the strategy used still includes 4 stages, namely Economic Salesmanship, Networking, Image Branding / Promotion, and Regulation Management.
\end{abstract}

\begin{abstract}
Abstrak
Sejak pertama kali muncul di kota Wuhan, Tiongkok, COVID 19 telah diumumkan oleh World Health Organization (WHO) sebagai suatu darurat kesehatan dunia. Bagi Indonesia pandemi COVID 19 telah menyebabkan neraca perdagangan mengalami defisit sejumlah 344,7 juta USD per April 2020. Situasi akibat pandemi COVID 19 membuat Indonesia membutuhkan strategi baru dalam menjaga arus lalu lintas perdagangan baik domestik maupun internasional. Dalam tulisan ini akan dibahas mengenai strategi baru dalam diplomasi ekonomi Indonesia sebagai instrumen dalam meningkatkan perdagangan dan investasi internasional. Tulisan ini juga akan membatasi penelitian di masa pemerintahan Presiden Joko Widodo baik sebelum maupun pada saat pandemi COVID-19. Adapun dalam pembahasannya akan digunakan konsep tahapan strategi diplomasi ekonomi negara berkembang dari Kishan Rana. Berdasarkan penelitian ditemukan bahwa beberapa dari strategi Indonesia yang pada masa sebelum COVID 19 mulai mengalami kesulitan. Akibatnya Indonesia menggunakan strategi baru yang disesuaikan dengan keadaan pada saat pandemi COVID 19 terjadi. Meskipun begitu, secara garis besar, strategi yang digunakan tetap mencakup 4 tahapan yaitu Economic Salesmanship, Networking, Image Branding/Promotion, dan Regulation Management.
\end{abstract}

\author{
Keywords \\ COVID-19, Diplomasi ekonomi, \\ Indonesia, Perdagangan \\ internasional
}

\section{Article History}

Received August 23, 2021

Revised October 21, 2021

Accepted October 26, 2021

Published November 18, 2021

\section{Corresponding Author}

Natsha Nabilla. Departemen

Ilmu Hubungan Internasional, Universitas Indonesia. Jl. Prof. DR. Selo Soemardjan, Pondok Cina, Kecamatan Beji, Kota Depok, Jawa Barat. 16424.

\section{Pendahuluan}

Sejak pertama kali muncul di kota Wuhan, Tiongkok, COVID 19 telah diumumkan oleh World Health Organization (WHO) sebagai suatu darurat kesehatan dunia. Hingga pada Juni 2020 COVID 19 telah menyebar di hampir 200 negara di dunia dengan jumlah infeksi mencapai kurang lebih 8 juta jiwa dan total kematian kurang lebih 400.000 jiwa. (WHO, 2020) Selain sebagai darurat 
kesehatan dunia, COVID 19 juga telah menyebabkan perekonomian global mengalami penurunan menuju krisis global jilid II. Adapun kerugiannya diprediksi lebih besar dibandingkan dengan krisis global di tahun 2008 (BBC.com, 2020). Dampak terhadap perekonomian dunia tidak lain disebabkan oleh adanya kebijakan-kebijakan yang ditetapkan oleh pemerintah negara-negara yang terinfeksi seperti menutup perbatasan negara, menutup bisnis, kewajiban menjaga jarak sosial dan karantina bagi masyarakat hingga menutup tempat-tempat publik.

Dalam bidang perdagangan, COVID 19 telah mengganggu lalu lintas perdagangan internasional. Hal tersebut salah satunya disebabkan oleh kemerosotan ekonomi Tiongkok sebagai ekonomi terbesar kedua di dunia. Pandemi COVID 19 telah membuat proyeksi pertumbuhan Produk Domestik Bruto (PDB) Tiongkok menurun dari angka 6,1\% di tahun 2019 menjadi 5,4\% di tahun 2020. Di sektor perdagangan, Tiongkok merupakan negara pengekspor terbesar dunia. Pada tahun 2018, nilai ekspor Tiongkok mencapai 2,5 triliun USD. Sementara dari sisi impor, negara ini menjadi pembeli terbesar kedua setelah Amerika Serikat. Berkurangnya aktivitas ekonomi Tiongkok akhirnya berdampak terhadap negara-negara pemasok seperti Korea Selatan, Jepang, Taiwan dan negara-negara Asia lainnya termasuk Indonesia (Lidwina dkk, 2020).

Di Indonesia, COVID 19 telah menyebabkan neraca perdagangan mengalami defisit sejumlah 344,7 juta USD per April 2020. Meskipun defisit, namun secara keseluruhan neraca perdagangan Indonesia pada Januari-April 2020 tetap surplus di angka 2,25 miliar USD. Merujuk pada pernyataan Kepala Departemen Komunikasi Bank Indonesia, Onny Widjanarko, angka tersebut dipengaruhi oleh adanya perlambatan dalam permintaan dunia serta terganggunya rantai penawaran global. Beliau juga menyatakan bahwa defisit neraca perdagangan pada bulan April 2020 dipengaruhi juga oleh defisit pada neraca perdagangan non migas dan migas (Hendartyo, 2020).

Dampak lainnya yang juga dirasakan berasal dari sektor manufaktur seperti industri pengolahan. Selama ini, kontribusi sektor manufaktur cukup signifikan terhadap ekonomi Indonesia (kisaran 19-20\%) dan produk yang berasal dari industri pengolahan telah menyumbang sekitar 70\% total ekspor Indonesia. Dengan begitu, kinerja industri manufaktur di Indonesia kemungkinan akan melambat seiring dengan meningkatnya kasus COVID 19 di Indonesia. Perlambatan lagi-lagi disebabkan oleh kenyataan bahwa mayoritas industri manufaktur di Indonesia masih bergantung pada impor, salah satunya dari Tiongkok. Kondisi ini berdampak besar pada kinerja perdagangan Indonesia di tahun 2020. Maka dari itu, Indonesia perlu mencari sumber bahan baku atau barang modal dari negara lain, meskipun tidak mudah dan harganya lebih mahal (Damuri \& Hirawan, 2020).

Sejak menjabat sebagai Presiden Republik Indonesia di tahun 2014, Joko Widodo (Jokowi) telah memperlihatkan pola kebijakan luar negeri yang berbeda dengan Presiden sebelumnya, Susilo Bambang Yudhoyono (SBY). Jika pada masa kepemimpinan SBY Indonesia lebih memperlihatkan pola kebijakan luar negeri yang outward looking, di masa Jokowi Indonesia lebih berorientasi pada kepentingan domestik atau lebih dikenal dengan istilah inward looking.

Indonesia di masa Jokowi memilih untuk menampilkan corak politik yang low profile dan tidak terlalu mementingkan forum-forum multilateral. Jokowi bahkan seringkali absen di dalam pertemuan multilateral. Adapun kehadiran Jokowi di dalam forum multilateral lebih dilatarbelakangi oleh agenda pertemuan bilateral dengan para delegasi. Di dalam pidato pelantikannya pada Oktober 2014, Beliau menyatakan bahwa Indonesia merupakan negara demokrasi dengan jumlah penduduk terbesar, populasi muslim terbesar dan ekonomi terbesar di kawasan Asia Tenggara. Oleh karena itu, Indonesia di bawah kepemimpinannya akan tetap 
mempertahankan prinsip bebas dan aktif namun dengan didukung oleh kekuatan pertahanan yang lebih kuat melalui tumpuan maritim global. Jokowi juga menekankan pentingnya program Nawa Cita dimana mencakup seruan untuk pembangunan infrastruktur dan keamanan nasional (Madu, 2017).

Pada masa kepemimpinan SBY, Indonesia menekankan pada diplomasi publik melalui Kementerian Luar Negeri. Di masa Jokowi, Indonesia menggunakan instrumen baru dengan istilah diplomasi ekonomi. Diplomasi telah menjadi instrumen negara dalam mencapai tujuan dan kepentingan nasionalnya. Diplomasi menurut G.R. Berridge (2015) adalah aktivitas politik yang memungkinkan aktor (negara) untuk dapat mencapai tujuan dan mempertahankan kepentingannya tanpa menggunakan kekerasan, propaganda maupun hukum. Diplomasi juga merupakan suatu istilah atau konsep yang luas dan elastis. Diplomasi secara tradisional dimaknai sebagai hubungan antara negara dengan entitas lainnya di dalam politik global yang dilakukan oleh agen resmi dengan cara damai. Seiring dengan semakin pentingnya isu ekonomi karena adanya perubahan orientasi dari militer menjadi pasar, maka hadir istilah diplomasi ekonomi sebagai suatu konsep di dalam ekonomi politik internasional (Berridge, 2015).

Diplomasi ekonomi berbeda dengan diplomasi klasik. Diplomasi ekonomi dipahami sebagai penggunaan sarana politik sebagai alat dalam negosiasi internasional yang bertujuan untuk meningkatkan kesejahteraan dan ekonomi nasional. Diplomasi ekonomi juga menggunakan instrumen ekonomi untuk meningkatkan stabilitas politik negara (Okano-Heijmans, 2011). Setelah perang dunia ke II, diplomasi ekonomi masih didominasi oleh kegiatan negosiasi yang dilakukan oleh agen resmi pemerintah/negara dalam menjalin hubungan dengan lawan negara lainnya. Namun setelah berakhirnya Perang Dingin, aktor-aktor yang terlibat di dalam diplomasi ekonomi tidak lagi hanya mencakup agen resmi negara tetapi juga aktor lainnya seperti Non-Governmental Organization (NGO), institusi ekonomi multilateral dan organisasi lainnya yang merupakan bagian dari global governance (Pigman, 2005). Dalam kasus Indonesia, diplomasi ekonomi dijelaskan melalui tiga tujuan spesifik yaitu: (1) investasi asing yang lebih banyak; (2) pasar yang lebih besar di luar negeri; (3) turis asing yang datang ke Indonesia (Haryono, 2019). Adapun investasi dan perdagangan adalah instrumen utama yang biasanya digunakan negara untuk mencapai kemakmuran ekonomi di era globalisasi.

Situasi akibat pandemi COVID 19 membuat Indonesia membutuhkan strategi baru dalam menjaga arus lalu lintas perdagangan dan investasi baik domestik maupun internasional. Dengan kata lain, Indonesia perlu untuk membuat strategi baru diplomasi ekonominya sebagai instrumen dalam meningkatkan perdagangan dan investasi Internasional. Dalam tulisan ini akan dibahas diplomasi ekonomi sektor perdagangan Indonesia di tengah Pandemi COVID 19. Adapun pertanyaan penelitian yang akan dijawab adalah bagaimana strategi diplomasi ekonomi sektor perdagangan Indonesia dalam menghadapi ancaman krisis global akibat pandemi COVID 19?

Selain untuk menjawab pertanyaan penelitian, tulisan ini juga bertujuan untuk menganalisis dan mengidentifikasi strategi diplomasi ekonomi Indonesia dalam sektor perdagangan terutama di masa pandemi COVID 19. Penelitian ini juga diharapkan dapat memberikan kontribusi akademis dalam menambah kajian konsep diplomasi ekonomi terutama konsep diplomasi ekonomi di negara berkembang dalam studi hubungan internasional.

Berdasarkan tinjauan pustaka yang telah dilakukan sebelumnya, ditemukan beberapa definisi dan konsep tentang diplomasi ekonomi terutama di Indonesia. Diplomasi Ekonomi didefinisikan sebagai suatu proses formulasi dan negosiasi kebijakan yang berkaitan dengan 
kegiatan produksi, pertukarang barang, jasa, tenaga kerja dan investasi dari negara lain (Rashid, 2005 cited in Killian, 2012). Salah satu karakter utama dari diplomasi ekonomi adalah karakternya yang sangat sensitif dan reaktif terhadap perubahan dan perkembangan pasar (Bayne \& Woolcock, 2007). Diplomasi akan gagal jika pasar menawarkan alternatif lain yang lebih menarik (Odell, 2000). Dengan kata lain, diplomasi ekonomi adalah jenis diplomasi yang berhadapan langsung dengan kekuatan pasar. Hal lainnya yang membedakan diplomasi ekonomi dengan diplomasi lainnya adalah peran dari sektor privat dalam proses negosiasi dan formulasi kebijakan yang cukup besar (Rashid, 2005 cited in Killian, 2012).

Diplomasi ekonomi dipahami sebagai penggunaan sarana politik dalam negosiasi internasional, dengan tujuan meningkatkan kemakmuran ekonomi nasional, dan penggunaan instrumen ekonomi untuk meningkatkan stabilitas politik negara (Okano-Heijmans, 2011). Konsep diplomasi ekonomi menjadi penting untuk dipelajari di dalam studi hubungan internasional. Hal ini dikarenakan, meskipun merupakan istilah yang baru, pada prakteknya diplomasi ekonomi telah digunakan negara dalam menjalankan hubungan luar negerinya sejak lama. Sebagai contoh, setelah Perang Dunia ke II, diplomasi ekonomi didominasi oleh kegiatan negosiasi yang dilakukan oleh agen resmi pemerintah/negara untuk berhubungan dengan negara lainnya (Bayne \& Woolcock, 2007). Memasuki masa Perang Dingin dan berlanjut setelahnya hingga munculnya globalisasi, aktor-aktor yang terlibat di dalam diplomasi ekonomi bukan hanya agen resmi negara, tetapi juga hadir aktor lainnya seperti Non-Governmental Organization (NGO), institusi ekonomi multilateral, dan global governance. Kehadiran aktor non negara berperan dalam mempengaruhi kebijakan pemerintah maupun sebagai pemain solo. Pigman (2005) dalam artikelnya menyatakan bahwa diplomasi bentuk baru ditandai dengan terlibatnya aktor non negara bersama-sama dengan pemerintah menjadi subjek dalam negosiasi/diplomasi. Namun, meskipun begitu, negara tetap menjadi aktor utama di dalam diplomasi ekonomi.

Selain melibatkan banyak aktor, diplomasi ekonomi juga dapat dilaksanakan dalam berbagai tingkatan di dalam sistem internasional. Jika di dalam tingkatan domestik praktek diplomasi atau negosiasi dalam pengambilan keputusan dilakukan oleh tingkatan aktor yang bersifat hirarkis dari mulai pemerintah sampai tingkatan masyarakat, di dalam tingkatan internasional, negosiasi atau diplomasi (dalam hal ini diplomasi ekonomi) dilakukan dalam interaksi antara beberapa tingkatan seperti bilateral, regional, plurilateral, dan multilateral (Bayne \& Woolcock, 2007).

Dalam penelitian ini, penulis menggunakan konsep diplomasi ekonomi di negara berkembang yang dikemukakan oleh Kishan S. Rana (2006, 2011). Diplomasi ekonomi didefinisikan oleh Rana sebagai suatu proses dimana negara memaksimalkan keuntungan nasionalnya di semua bidang kegiatan seperti perdagangan, investasi dan bentuk lainnya yang menguntungkan secara ekonomi. Hal ini dapat dilakukan dalam dimensi bilateral, regional dan multilateral yang masing-masing memiliki peranan tersendiri. Aktor yang terlibat di dalamnya bukan lagi dimonopoli oleh entitas negara, tetapi juga melibatkan berbagai kemitraan dengan aktor non-negara (Rana, 2006).

Rana juga menyatakan di dalam salah satu bagian dari bukunya yang berjudul 21st Century Diplomacy: A Practitioner's Guide bahwa setidaknya ada empat tahapan yang akan dilakukan oleh negara dalam menjalankan diplomasi ekonomi. Keempat tahapan tersebut antara lain: (1) Economic Salesmanship, dimana negara, biasanya melalui duta besar dan diplomat, melakukan promosi terhadap ekspor dan mobilisasi FDI; (2) Networking, yang merupakan tahapan ketika negara sudah 
melibatkan kemitraan dengan kamar dagang, perusahaan, think-tank, serta aktor non negara lainnya, baik di dalam maupun luar negeri dalam kegiatan diplomasi ekonomi; (3) Image Building/ Image Promotion, atau promosi citra dan nama baik negara dengan melibatkan kemitraan publik-swasta; dan (4) Regulation Management, yaitu tahapan yang melibatkan aktivitas-aktivitas seperti perencanaan dan negosiasi-negosiasi regulasi seperti perdagangan sekaligus melakukan diplomasi regional melalui pembentukan kelompok baru yang inovatif. Dalam tahapan ini biasanya dibutuhkan adanya koalisi domestik antara lembaga resmi dan swasta dalam menetapkan standar/kebijakan domestik baru serta membawa entitas bisnis, think-tank dan LSM ke dalam proses negosiasi eksternal (Rana, 2011).

Empat tahapan dari Rana tersebut, akan digunakan penulis dalam menjelaskan tahapan strategi dalam diplomasi ekonomi sektor perdagangan (diplomasi perdagangan) Indonesia di tengah Pandemi COVID-19 seperti yang dipaparkan dalam gambaran operasionalisasi konsep berikut ini.

\section{Gambar 1.1. Operasionalisasi Konsep}

\section{Tahapan Strategi Diplomasi Ekonomi}
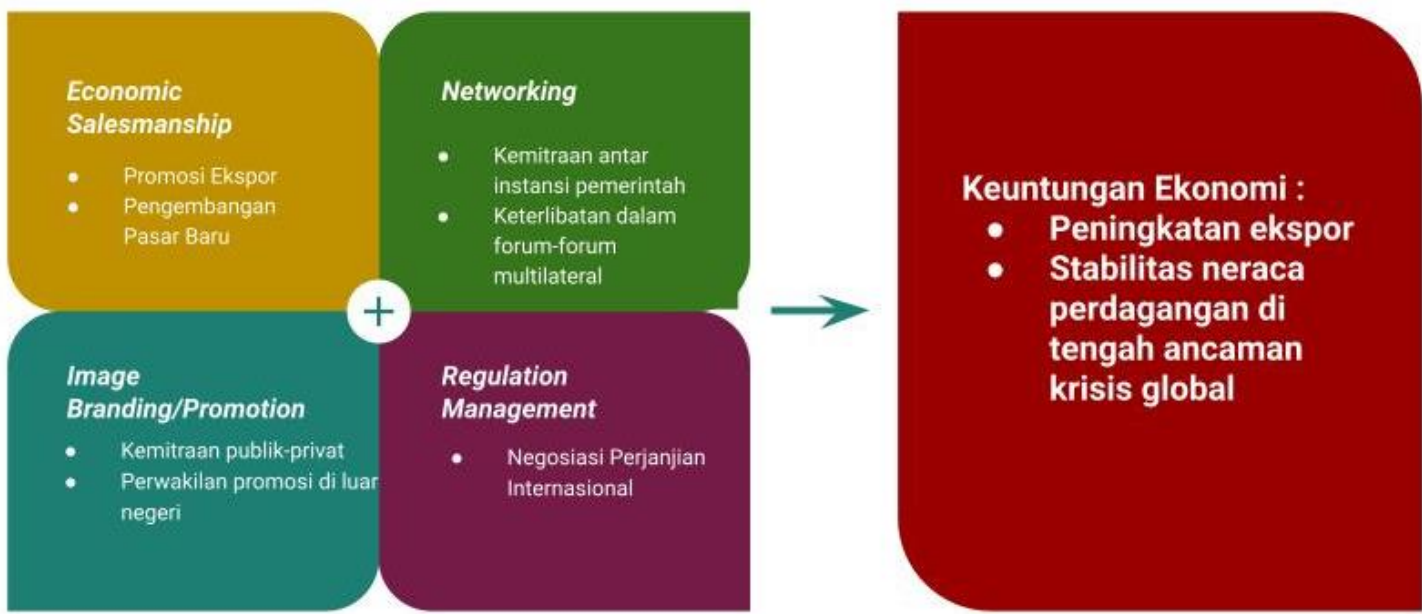

Sumber : Rana (2011) diolah kembali oleh penulis

\section{Metode Penelitian}

Metode Penelitian yang digunakan adalah metode penelitian kualitatif. Penelitian kualitatif memiliki sifat induktif dimana peneliti pada umumnya mengeksplorasi makna dan wawasan dalam situasi tertentu (Strauss \& Cobin, 2008; Levitt et.al., 2017). Metode induktif cenderung bermula dari bawah, yaitu pengumpulan fakta-fakta dan data di lapangan. Data-data tersebut kemudian dicari kesamaannya, baik pola maupun prinsip, untuk kemudian ditarik ke dalam sebuah kesimpulan. Adapun sumber data yang digunakan adalah studi pustaka yang berasal dari dokumen resmi, buku, jurnal, laporan penelitian, dan lain-lain. 


\section{Hasil dan Pembahasan}

Berdasarkan uraian latar belakang, kerangka analisa dan metode penelitian sebelumnya, di dalam bagian ini akan diuraikan mengenai strategi diplomasi ekonomi khususnya di sektor perdagangan Indonesia dalam menghadapi ancaman COVID 19. Namun, sebelum dibahas mengenai strategi baru yang digunakan, dalam tulisan ini juga akan diuraikan terlebih dahulu bagaimana gambaran umum diplomasi ekonomi Indonesia, yang kemudian akan dilanjutkan dengan strategi diplomasi ekonomi Indonesia sektor perdagangan sebelum pandemi COVID 19.

\section{Gambaran Umum Diplomasi Ekonomi Indonesia}

Diplomasi ekonomi merupakan media yang paling dominan dan menjadi salah satu kunci utama keberhasilan negara-negara berkembang dalam memanfaatkan peluang dari globalisasi tidak terkecuali Indonesia. Di tahun 2011, Indonesia sendiri telah menandatangani setidaknya 146 perjanjian internasional dan meratifikasi 26 perjanjian dimana 60\% diantaranya merupakan kerjasama ekonomi (Kemlu, 2012). Di dalam penelitiannya, Killian (2012) mencoba untuk memetakan tipologi dari diplomasi ekonomi Indonesia menggunakan kerangka dari Rana (2007). Hasil dari penelitiannya ditemukan bahwa diplomasi ekonomi Indonesia masih bersifat tradisional, meskipun beberapa dari aktivitasnya sudah tergolong pada tipe niche-focused dan evolving (Killian, 2012).

Diplomasi ekonomi menjadi salah satu prioritas utama dalam kebijakan luar negeri Indonesia. Hal ini tertuang di dalam Arah kebijakan dan Strategi Renstra Kemlu Tahun 2015-2019 yang menuliskan 8 arah kebijakan Indonesia. Adapun 4 pilar diplomasi ekonomi Indonesia antara lain : (1) melakukan perluasan dan peningkatan akses pasar produk Indonesia dengan mendorong perubahan mindset para diplomat Indonesia agar lebih aktif dengan turun langsung ke lapangan; (2) penguatan kapasitas dan sumber daya perwakilan RI di pasar non tradisional atau untapped market, (3) mendorong investasi asing pada sektor prioritas Indonesia dan melindungi investasi Indonesia di luar negeri; (4) memanfaatkan ASEAN Economic Community (AEC). Singkatnya, aspek penting di dalam diplomasi ekonomi Indonesia terbagi menjadi 3 yaitu perdagangan, investasi dan pariwisata (Trade, Tourism, Investment/ TTI) (Sabaruddin, 2016).

Dalam menjalankan kerjasama TTI, Indonesia telah memetakan negara-negara mitra baik dalam pasar non tradisional maupun pasar tradisional. Pasar non tradisional adalah negara-negara yang potensial secara ekonomi dan dianggap prospektif sebagai tujuan pasar. yang termasuk ke dalam kategori pasar non tradisional bagi Indonesia antara lain negara-negara di kawasan Amerika Latin, Eropa Tengah dan Timur, Afrika, Asia Tengah dan Pasifik Selatan. Sedangkan pasar tradisional adalah mitra Indonesia seperti Amerika Serikat (AS) dan Eropa Barat yang telah memiliki hubungan kerjasama ekonomi sejak lama. Dalam implementasinya, negara-negara di kategori pasar tradisional masih lebih dominan dan mendapatkan perhatian dibandingkan di pasar non tradisional (Sabaruddin, 2016).

\section{Strategi Diplomasi Ekonomi Sektor Perdagangan Indonesia sebelum dan pada masa pandemi COVID 19}

Arah kebijakan politik luar negeri Indonesia di periode pertama Jokowi dimuat di dalam dokumen quick wins yang dibahas presiden dan anggota kabinet dalam sidang kabinet kerja pada tahun 2014. Program-program dalam quick wins dijalankan melalui tiga kata kunci yaitu perdagangan, maritim dan investasi (Bappenas 2014 cited in Haryono 2019). Adapun arah kebijakan 
luar negeri Indonesia pada masa pemerintahan Jokowi antara lain: (1) penanganan perbatasan; (2) pemantapan peran Indonesia di ASEAN; (3) penguatan diplomasi ekonomi; (4) peningkatan kualitas perlindungan hak dan keselamatan warga negara/badan hukum Indonesia (WNI/BHI) di luar negeri khususnya perlindungan terhadap Tenaga Kerja Indonesia (TKI) dan (5) peran Indonesia dalam kerjasama global (Kemlu, 2015 cited in Haryono 2019).

Dalam uraian arahan kebijakan politik luar negeri tersebut, salah satu yang menjadi fokus utama Indonesia adalah diplomasi ekonomi. Diplomasi ekonomi dalam arah kebijakan luar negeri Indonesia tergolong merupakan suatu hal yang baru, hal ini mengingat dalam perjalanan diplomasi Indonesia sebelumnya yang masih didominasi oleh isu politik dan keamanan. Kementerian Luar Negeri (2015) juga menyatakan bahwa selama ini diplomasi telah memberi keuntungan politis bagi Indonesia di tingkat internasional. keuntungan politis tersebut kemudian dapat dimanfaatkan untuk mendapatkan keuntungan ekonomi. Oleh karenanya, lima tahun kepemimpinan Jokowi akan fokus pada diplomasi ekonomi dengan mendukung penghapusan non-tariff barrier serta pembukaan pasar yang dianggap prospektif seperti kawasan Eropa Timur dan Tengah, Kawasan Afrika, Amerika Utara dan Tengah, Amerika Selatan, Karibia dan kawasan Asia lainnya yang tengah mengalami pertumbuhan pesat (Kemlu, 2015 cited in Haryono, 2019).

Memasuki periode kedua kepemimpinan Jokowi, diplomasi ekonomi tetap menjadi fokus utama dari kebijakan luar negeri Indonesia. Menurut Menteri Luar Negeri, Retno L.P. Marsudi, diplomasi ekonomi Indonesia akan tetap pada upaya peningkatan perdagangan dan investasi (Supriatin, 2019). Diplomasi ekonomi Indonesia pada tahun 2017 hingga awal 2020 nampaknya berkembang ke dalam cakupan yang lebih luas lagi. Hal ini, menurut penulis, sejalan dengan apa yang dikemukakan oleh Kishan S. Rana (2006). Menurut Rana, tipe diplomasi ekonomi yang dikembangkan oleh negara berkembang berfokus pada kemitraan publik-swasta. Jika kita ingin melihat totalitas diplomasi ekonomi yang dilakukan oleh suatu negara dapat dilihat melalui kemitraan publik-swasta secara luas. Aktor bisnis akan dapat bekerjasama dengan negara dalam memajukan kepentingan negara (Rana, 2011). Untuk dapat mencapai titik kemitraan publik-swasta yang luas, negara akan melalui tahapan dan strategi dalam pelaksanaan diplomasi ekonominya. Adapun tahapan dan strategi diplomasi ekonomi Indonesia di bidang perdagangan dalam menghadapi COVID-19 antara lain:

\section{Economic Salesmanship}

Tahapan dan strategi pertama dalam menjalankan diplomasi ekonomi Indonesia terutama dalam hal promosi sektor perdagangan adalah melalui economic salesmanship. Economic salesmanship didefinisikan oleh Rana sebagai suatu tahapan dimana negara menggunakan agen resminya (diplomat dan duta besar) dalam mempromosikan perdagangan serta investasi langsung di luar negeri. Di Indonesia, strategi economic salesmanship ini diperkuat oleh pernyataan Presiden Joko Widodo yang mengungkapkan peran diplomat Indonesia sebagai salesperson dalam mempromosikan Indonesia. Lebih lanjut, promosi dan diplomasi ekonomi yang dijalankan tidak hanya melibatkan Kementerian Luar Negeri tetapi juga instansi lainnya seperti Kementerian Perdagangan, Kementerian Keuangan, Kementerian Pariwisata, Bank Indonesia dan Badan Koordinasi Penanaman Modal (BKPM). Instansi-instansi tersebut turut berperan penting dalam menjalankan diplomasi ekonomi Indonesia (Sabaruddin, 2016).

Keinginan Jokowi akan tugas Duta Besar Indonesia dan kepala perwakilan disampaikan olehnya dalam acara rapat kerja di Kementerian Luar Negeri. Menurut Jokowi, diplomasi yang 
fokus terhadap ekonomi tidak terlepas dari posisi neraca perdagangan Indonesia yang saat itu masih defisit. Dengan menunjuk Duta Besar sebagai sales di luar negeri diharapkan akan membuat surplus neraca perdagangan dan menarik investasi yang masuk ke tanah air (Jumadil Akhir, 2015).

Dalam upaya mempromosikan Indonesia, Kedutaan Besar Republik Indonesia di luar negeri melakukan berbagai macam kegiatan salah satunya adalah ikut aktif di dalam Pameran atau Expo dengan membuka booth khusus Indonesia. Sebagai contoh, KBRI Indonesia di Mesir yang menggelar Pameran Dagang Indonesia dalam acara memperingati 70 tahun hubungan diplomatik RI-Mesir (Michaela, 2017). Sedangkan di Tunisia, KBRI Tunisia telah menyelenggarakan kegiatan business meeting/ business forum melalui acara Indonesia Economic Briefing, Investment and Infrastructure sector in Indonesia guna mempertemukan para pelaku usaha di Tunisia dengan Indonesia (Kemlu, 2019).

Memasuki masa pandemi COVID-19, seluruh perwakilan perdagangan RI yaitu Atase perdagangan, ITPC di 33 negara serta KDEI kesulitan untuk melakukan pameran dan mengumpulkan para buyer. Adapun Economic Partnership pada masa pandemi difokuskan pada kerjasama multilateral salah satunya melalui ASEAN dan mitra dialognya. Indonesia juga mendorong penguatan kerjasama regional negara-negara di Kawasan Samudera Hindia yang tergabung dalam Indian Ocean Rim Association (IORA). Bersama IORA, Indonesia mendorong adanya pengembangan vaksin dan anti-virus, memastikan arus obat-obatan dan alat medis yang terjangkau bagi masyarakat kecil, serta merumuskan pemberian bantuan yang tepat terhadap nelayan kecil, petani dan pengusaha UMKM (Kemlu, 2020).

\section{Networking}

Tahapan selanjutnya di dalam diplomasi ekonomi adalah tahapan networking. Dalam tahapan strategi ini, negara akan melakukan sebanyak-banyaknya kemitraan baik antar instansi pemerintah maupun dengan pihak swasta, kamar dagang, dan aktor lainnya di dalam negeri maupun di luar negeri. Networking yang dilakukan oleh Indonesia dalam hal perluasan pasar salah satunya dengan melakukan ekspansi BUMN ke pasar Afrika melalui PT Wijaya Karya (WIKA). Ekspansi juga melibatkan beberapa Lembaga seperti Lembaga Pembiayaan Ekspor Indonesia (LPEI) dan Kamar Dagang dan Industri (KADIN) (Difa, 2019). Adapun Networking di dalam negeri dilakukan dengan cara melibatkan beberapa kementerian seperti Kementerian Perekonomian, Timnas PEPI (Peningkatan Ekspor dan Peningkatan Investasi), Kementerian Perdagangan dan Kementerian Keuangan (Kurniawan, 2014).

Di luar negeri, Networking juga dilakukan Indonesia menggunakan forum-forum multilateral seperti Trade Expo Indonesia 2017, Indonesia Fair 2018, Indonesia-Africa Forum 2018 \& 2019, IMF-WBG 2018 dan WEF 2020. Selanjutnya, di masa pandemi COVID 19 hampir serupa dengan Economic partnership. pada tahapan strategi networking, Indonesia berhasil menggaet beberapa pebisnis internasional seperti Alibaba Foundation- Jack Ma Foundation dalam penanganan COVID 19 (Kemlu, 2012). Kementerian Luar Negeri juga melakukan beberapa kali webinar pengganti forum promosi yang selama ini dilakukan dengan mengajak pelaku-pelaku bisnis Indonesia untuk dapat jeli dalam mencari peluang ekspor. Salah satu contoh dari webinar yang dimaksud yaitu Webinar "Potensi Bisnis Indonesia-Kanada" dimana webinar ini bertujuan untuk mengidentifikasi peluang bisnis serta mendorong pelaku bisnis dalam menarik potensi pasar niche misalnya produk-produk makanan dan rempah-rempah. Hal ini dilakukan demi mendorong pelaku bisnis untuk tetap semangat di tengah situasi pandemi COVID 19. 
Kegiatan lainnya yaitu kegiatan kerjasama antara Pemerintah dengan Gabungan Pengusaha Makanan dan Minuman Indonesia (GAPPMI) melalui webinar guna mendorong pasar ekspor produk pangan olahan. Indonesia juga bersama Organisasi Kopi Internasional (ICO) bekerja sama untuk membantu petani kopi di tengah Pandemi COVID 19 (Kemendag, 2020).

\section{Image Building/Image Promotion}

Tahapan Image Building/Image Promotion biasanya dilakukan oleh negara melalui promosi citra baik negara. Untuk Indonesia, promosi ditekankan pada 3 kunci utama tujuan diplomasi ekonomi yaitu promosi perdagangan, promosi investasi dan promosi pariwisata. Promosi citra di periode pertama kepemimpinan Jokowi dilakukan melalui kunjungan-kunjungan kenegaraan Joko Widodo.

Promosi citra Indonesia di luar negeri saat ini dicapai melalui pengembangan strategi komunikasi dan branding bangsa secara holistic. Hal ini dijalankan melalui partisipasi Indonesia di dalam pameran perdagangan Internasional atau yang diselenggarakan di Indonesia sendiri seperti Trade Expo Indonesia. Selain secara fisik, Indonesia juga sudah mulai menyediakan pameran virtual produk Indonesia di internet dengan target pembeli asing potensial melalui situs www.dgnedve.com. Situs tersebut menyediakan one-stop sumber informasi produk dengan gambar, kutipan harga dan rincian kontak perusahaan yang berpartisipasi. Adapun pembaharuan dilakukan setiap dua kali setahun (Kemendag, 2019). Di luar negeri, Indonesia juga mendirikan perwakilan perdagangan RI yaitu Indonesian Trade Promotion Center (ITPC) yang tersebar di 33 negara.

Di tengah pandemi COVID 19, Indonesia kehilangan banyak kesempatan untuk dapat membuat pameran dagang ataupun mengikuti pameran dagang di luar negeri. Oleh karena itu, strategi baru yang dilakukan oleh Indonesia adalah dengan cara membuat suatu event virtual bertemakan business matching. Hal ini dilakukan untuk dapat tetap melakukan promosi namun dengan cara digitalisasi. Promosi secara virtual juga dilakukan Indonesia dengan memanfaatkan forum kerjasama perdagangan internasional seperti G20 (Kemendag, 2020). Indonesia juga tetap ikut serta di dalam pameran-pameran dagang lainnya yang dilaksanakan secara virtual, salah satunya, Pameran NYNOW 2020 yang juga beradaptasi menjadi event virtual akibat adanya pandemi COVID 19. NYNOW sendiri merupakan pameran dagang dan kriya terbesar di Amerika Utara. NYNOW menghadirkan lebih dari 25.000 buyers/pembeli profesional dan menampilkan lebih dari 2500 peserta pameran dari berbagai belahan dunia. NYNOW merupakan ajang kriya terbesar yang menjadi kesempatan bagi negara-negara di dunia untuk unjuk gigi dan berkompetisi menjadi pemain utama dalam pasar kerajinan tangan global (Kemlu, 2018).

\section{Regulation Management}

Tahapan akhir yang dikemukakan oleh Rana (2006 \& 2011) adalah tahapan regulation management. Dalam tahapan strategi ini, negara biasanya membentuk koalisi domestik antara lembaga resmi dan swasta dalam menetapkan standar/kebijakan domestik baru. Indonesia pada saat ini berada di tahap diplomasi ekonomi ini. Dimana Indonesia tengah banyak membenahi regulasi-regulasi domestik guna mencapai tujuan nasional Indonesia. Di akhir tahun 2019 sendiri, Pemerintah Indonesia telah menargetkan 11 perjanjian dagang yang akan selesai di tahun 2020 . Dari target tersebut terdapat 5 prioritas perjanjian kerjasama yaitu Perjanjian Kerjasama ekonomi Komprehensif Indonesia - Uni Eropa (IEU-CEPA), Perjanjian Perdagangan Preferensial Indonesia-Maroko (IM-PTA), Indonesia Tunisia PTA, Indonesia Bangladesh PTA, dan Indonesia 
- Turki CEPA. Di tahun 2019 sendiri, Indonesia telah menyelesaikan sejumlah perjanjian dagang salah satunya adalah Indonesia-Australia CEPA (Basith, 2020).

Regulation Management menjadi strategi yang paling banyak dilakukan oleh Pemerintah Indonesia di masa pandemi COVID 19. Bahkan yang menjadi respon pertama sekaligus sebagai langkah preventif Kementerian Perdagangan adalah dengan mengeluarkan larangan sementara impor binatang hidup dari Tiongkok. Hal ini diatur di dalam Peraturan Menteri Perdagangan Nomor 10 Tahun 2020. Kementerian Perdagangan juga mengeluarkan Peraturan Menteri Perdagangan Nomor 23 Tahun 2020 tentang larangan sementara ekspor antiseptik, bahan baku masker, alat pelindung diri dan masker sebagai tanggapan dari langkanya bahan-bahan tersebut di dalam negeri. Selain itu, Pemerintah juga mengeluarkan Surat Edaran Nomor 12 Tahun 2020 tentang pengembalian aktivitas perdagangan selama pandemi dan normal baru yang berisi penjabaran pedoman dan protokol yang harus diikuti sebagai bagian dari kampanye New Normal pemerintah (Kemendag, 2020).

Secara singkat keempat strategi yang telah diuraikan sebelumnya dapat dilihat di dalam tabel berikut :

Tabel 1.1. Strategi Diplomasi Ekonomi Indonesia di Masa Pandemi Covid 19 dalam menjaga stabilitas neraca perdagangan

\begin{tabular}{|c|c|c|c|}
\hline Economic Salesmanship & Networking & $\begin{array}{c}\text { Image } \\
\text { Branding/Promotion }\end{array}$ & Regulation Management \\
\hline $\begin{array}{l}\text { 1. Memperkuat peran } \\
\text { diplomat Indonesia } \\
\text { sebagai salesperson } \\
\text { dalam } \\
\text { mempromosikan } \\
\text { Indonesia } \\
\text { 2. Melibatkan nstansi } \\
\text { lainnya seperti } \\
\text { Kementerian } \\
\text { Perdagangan, } \\
\text { Kementerian } \\
\text { Keuangan, } \\
\text { Kementerian } \\
\text { Pariwisata, Bank } \\
\text { Indonesia dan Badan } \\
\text { Koordinasi } \\
\text { Penanaman Modal } \\
\text { (BKPM } \\
\text { 3. Ikut aktif di dalam } \\
\text { Pameran atau Expo } \\
\text { dengan membuka } \\
\text { booth khusus } \\
\text { Indonesia (virtual pada } \\
\text { saat pandemi) } \\
\text { 4. Kerjasama multilateral } \\
\text { salah satunya melalui }\end{array}$ & $\begin{array}{l}\text { 1. Melakukan sebanyak- } \\
\text { banyaknya kemitraan } \\
\text { baik antar instansi } \\
\text { pemerintah maupun } \\
\text { dengan pihak swasta, } \\
\text { kamar dagang, dan } \\
\text { aktor lainnya di dalam } \\
\text { negeri maupun di luar } \\
\text { negeri. } \\
\text { 2. Melakukan ekspansi } \\
\text { BUMN ke pasar } \\
\text { Afrika } \\
\text { 3enggunakan forum- } \\
\text { forum multilateral } \\
\text { seperti Trade Expo } \\
\text { Indonesia } 2017 \text {, } \\
\text { Indonesia Fair } 2018, \\
\text { Indonesia-Africa } \\
\text { Forum } 2018 \& 2019 \text {, } \\
\text { IMF-WBG } 2018 \text { dan } \\
\text { WEF } 2020\end{array}$ & $\begin{array}{l}\text { 1. Menyediakan } \\
\text { pameran virtual } \\
\text { produk Indonesia } \\
\text { di internet dengan } \\
\text { target pembeli } \\
\text { asing potensial } \\
\text { melalui situs } \\
\text { www.dgnedve.co } \\
\text { m. } \\
\text { Membuat suatu } \\
\text { event virtual } \\
\text { bertemakan } \\
\text { business matching } \\
\text { Memanfaatkan } \\
\text { forum kerjasama } \\
\text { perdagangan } \\
\text { internasional } \\
\text { seperti G20 } \\
\text { 4kut serta di } \\
\text { dalam pameran- } \\
\text { pameran dagang } \\
\text { lainnya yang } \\
\text { dilaksanakan } \\
\text { secara virtual, } \\
\text { salah satunya, } \\
\text { Pameran }\end{array}$ & $\begin{array}{l}\text { 1. Mengeluarkan } \\
\text { larangan sementara } \\
\text { impor binatang hidup } \\
\text { dari Tiongkok } \\
\text { (Peraturan Menteri } \\
\text { Perdagangan Nomor } \\
\text { 10 Tahun 2020) } \\
\text { 2. Mengeluarkan } \\
\text { Peraturan Menteri } \\
\text { Perdagangan Nomor } \\
\text { 23 Tahun 2020 } \\
\text { tentang larangan } \\
\text { sementara ekspor } \\
\text { antiseptik, bahan baku } \\
\text { masker, alat pelindung } \\
\text { diri dan masker } \\
\text { sebagai tanggapan } \\
\text { dari langkanya bahan- } \\
\text { bahan tersebut di } \\
\text { dalam negeri } \\
\text { 3. Mengeluarkan Surat } \\
\text { Edaran Nomor } 12 \\
\text { Tahun } 2020 \text { tentang } \\
\text { pengembalian } \\
\text { aktivitas perdagangan } \\
\text { selama pandemi dan }\end{array}$ \\
\hline
\end{tabular}




\begin{tabular}{|c|c|c|}
\hline $\begin{array}{l}\text { ASEAN dan mitra } \\
\text { dialognya. Indonesia } \\
\text { juga mendorong } \\
\text { penguatan kerjasama } \\
\text { regional negara-negara } \\
\text { di Kawasan Samudera } \\
\text { Hindia yang tergabung } \\
\text { dalam Indian Ocean } \\
\text { Rim Association } \\
(\text { IORA) }\end{array}$ & NYNOW 2020 & $\begin{array}{l}\text { normal baru yang } \\
\text { berisi penjabaran } \\
\text { pedoman dan protokol } \\
\text { yang harus diikuti } \\
\text { sebagai bagian dari } \\
\text { kampanye New } \\
\text { Normal pemerintah }\end{array}$ \\
\hline
\end{tabular}

Sumber: Diolah oleh peneliti

\section{Kesimpulan}

Berdasarkan uraian diatas, dapat terlihat bahwa Indonesia di tengah pandemi COVID 19 menjalankan beberapa strategi baru di dalam diplomasi ekonominya. Jika merujuk pada kerangka yang digunakan yang ditulis oleh Rana (2006, 2011), pertama, dalam tahapan strategi Economic Partnership pada masa pandemi difokuskan pada kerjasama multilateral salah satunya melalui ASEAN dan mitra dialognya. Indonesia juga mendorong penguatan kerjasama regional negaranegara di Kawasan Samudera Hindia yang tergabung dalam Indian Ocean Rim Association (IORA). Bersama IORA, Indonesia mendorong adanya pengembangan vaksin dan anti-virus, memastikan arus obat-obatan dan alat medis yang terjangkau bagi masyarakat kecil, serta merumuskan pemberian bantuan yang tepat terhadap nelayan kecil, petani dan pengusaha UMKM. Kedua, dalam tahapan Networking, Indonesia berhasil menggaet beberapa pebisnis internasional seperti Alibaba Foundation- Jack Ma Foundation dalam penanganan COVID 19. (Kemlu, 2012) Kementerian Luar Negeri juga melakukan beberapa kali webinar pengganti forum promosi yang selama ini dilakukan dengan mengajak pelaku-pelaku bisnis Indonesia untuk dapat jeli dalam mencari peluang ekspor. Strategi terakhir yaitu, regulation management, merupakan strategi yang paling awal digunakan Indonesia ketika pandemi COVID 19 datang. Bahkan yang menjadi respon pertama sekaligus sebagai langkah preventif Kementerian Perdagangan adalah dengan mengeluarkan larangan sementara impor binatang hidup dari Tiongkok. Hal ini diatur di dalam Peraturan Menteri Perdagangan Nomor 10 Tahun 2020. Kementerian Perdagangan juga mengeluarkan Peraturan Menteri Perdagangan Nomor 23 Tahun 2020 tentang larangan sementara ekspor antiseptik, bahan baku masker, alat pelindung diri dan masker sebagai tanggapan dari langkanya bahan-bahan ini di dalam negeri. Dari uraian analisa sebelumnya, dapat disimpulkan bahwa beberapa dari strategi Indonesia yang pada masa sebelum COVID 19 mulai mengalami kesulitan. Akibatnya Indonesia menggunakan strategi baru yang disesuaikan dengan keadaan pada saat pandemi COVID 19 terjadi. Meskipun begitu, secara garis besar, strategi yang digunakan tetap mencakup 4 tahapan yaitu Economic Salesmanship, Networking, Image Branding/Promotion, dan Regulation Management.

\section{Referensi}

Basith (November 18, 2020). Ini lima prioritas perjanjian dagang yang dikejar Indonesia tahun 2020. Kontan.co.id. Retrieved from https://nasional.kontan.co.id/news/ini-lima-prioritasperjanjian-dagang-yang-dikejar-indonesia-tahun-2020 
Bayne, N., \& Woolcock, S. (Eds.). (2016). The new economic diplomacy: decision-making and negotiation in international economic relations. Ashgate Publishing, Ltd.

Berridge, G. R. (2015). Diplomacy: theory and practice. Springer.

Damuri \& Hirawan. (2020). Mengukur Dampak COVID-19 pada Pertumbuhan Ekonomi dan Perdagangan Indonesia 2020. CSIS Commentaries. Retrieved from https://www.csis.or.id/publications/mengukur-dampak-covid-19-pada-pertumbuhanekonomi-dan-perdagangan-indonesia-2020

Haryono, E. (2019). Economic Diplomacy as Indonesian Foreign Policy Orientation in 20152018: Challenges and Opportunities. Global Strategis, 13(2), 46-61.

Hendartyo. (May 16, 2020). Pandemi COVID 19 Bikin Neraca Perdagangan Indonesia Defisit. Tempo.co. Retrieved from https://bisnis.tempo.co/read/1342879/pandemi-covid-19bikin-neraca-perdagangan-indonesia-defisit

Jumadil Akhir (2015) Jokowi Ingatkan agar Dubes jadi Sales. Okefinance dalam https://economy.okezone.com/read/2015/02/02/320/1100211/jokowi-ingatkan-agardubes-jadi-sales

Kemendag. (2020). Kemendag Terus Dobrak Pasar Ekspor Pangan Olahan Tingkatkan Neraca Perdagangan di Tengah Pandemi Covid-19.

Kemendag. (2020). Lawan COVID-19: Pimpin Pertemuan Dewan Kopi Internasional, Indonesia Bertekad Bantu Petani Kopi di Tengah Pandemi COVID-19.

Kemendag. (2020). Mendag Jalankan Langkah Strategis Bidang Perdagangan di Masa Pandemi Covid-19.

Kemlu (2020). Lawan COVID-19, Indonesia Dorong Kemitraan di Kawasan Samudera Hindia. Kemlu (2020). Mesin Diplomasi ASEAN Terus Bekerja Hadapi COVID-19.

Kemlu (2020). Wamenlu RI: Manfaatkan Peluang Ekonomi di Tengah COVID-19.

Kemlu. (2018). Batik Indonesia Memenangkan Penghargaan Best New Product pada NY NOW 2018 Pameran Dagang dan Kriya Terbesar di Amerika Utara.

Kemlu. (2020). Indonesia Kembangkan Kerja Sama dengan Alibaba Foundation dan Jack Ma Foundation untuk Penanganan COVID-19.

Kencana, M.R.B. (2018) Ini Hasil Diplomasi Ekonomi ala Jokowi-JK. Liputan6 dalam https://www.liputan6.com/bisnis/read/3672549/ini-hasil-diplomasi-ekonomi-ala-jokowijk

Killian, P. M. (2012). Paradigma dan Problematika Diplomasi Ekonomi Indonesia. Global \& Strategis, 6(2), 171-186.

Kurniawan, A. (2014). Diplomasi Ekonomi Indonesia dan Thailand terhadap Pasar Timur Tengah. Jurnal Ilmu Sosial dan Ilmu Politik, 17(3), 254-271.

Lane, M. (2015). Amidst Indonesia's Nationalist Atmospherics: The Changing Politics of Jokowi's Economics. Institute of Southeast Asian Studies.

Levitt, H. M., Motulsky, S. L., Wertz, F. J., Morrow, S. L., \& Ponterotto, J. G. (2017). Recommendations for Designing and Reviewing Qualitative Research in Psychology: Promoting Methodological Integrity. Qualitative Psychology, 4(1), 2-22.

Lidwina, dkk. (March 16, 2020). Ekonomi Dunia Menanggung Beban COVID 19. Katadata.co.id. Retrieved from https://katadata.co.id/analisisdata/2020/03/16/ekonomidunia-menanggung-beban-covid-19 
Madu, L. (2015). Indonesia's Foreign Policy under President Jokowi: More Domestic and Nationalist Orientations. Southeast Asia, 37(1), 6.

Michaela (2017) Promosi Indonesia, KBRI Kairo Gelar Pameran Dagang dan Investasi. Medcom.id dalam https://www.medcom.id/internasional/dunia/0k8j91WN-promosiindonesia-kbri-kairo-gelar-pameran-dagang-dan-investasi

Negara, S. D. (2015). Rising Economic Nationalism in Indonesia: Will This Time be Different? ISEAS Perspective, 59, 1-12.

Okano-Heijmans, M. (2011). Conceptualizing economic diplomacy: The crossroads of international relations, economics, IPE and diplomatic studies. The Hague journal of diplomacy, 6(1-2), 7-36.

Pigman, G. A. (2005). Making room at the negotiating table: The growth of diplomacy between nation-state governments and non-state economic entities. Diplomacy and Statecraft, 16(2), 385-401.

Pigman, G. A. (2007). The World Economic Forum: A multi-stakeholder approach to global governance. Routledge.

Pramudyani (2019) Empat Strategi Diplomasi Ekonomi Indonesia di Afrika. Antaranews.com dalam https://www.antaranews.com/berita/1135611/empat-strategi-diplomasi-ekonomiindonesia-di-afrika

Rana, K. S. (2007). Economic diplomacy: the experience of developing countries. The New Economic Diplomacy: Decision-Making and Negotiations in International Economic Relations. Aldershot: Ashgate.

Rana, K. S. (2011). 21st-Century Diplomacy: A Practitioner's Guide. Bloomsbury Publishing USA.

Rosada, Q. I. (2016). Diplomasi Ekonomi Indonesia Terhadap World Economic Forum (Wef) Pada Masa Pemerintahan Presiden Sby Periode Tahun 2009-2014 (Bachelor's thesis, Jakarta: Fakultas Ilmu Sosial dan Ilmu Politik UIN Syarif Hidayatullah).

Sabaruddin, S. S. (2016). Grand Design Diplomasi Ekonomi Indonesia: Sebuah Pendekatan Indeks Diplomasi Ekonomi. Jurnal Ilmiah Hubungan Internasional, 12(1), 69-90.

Satya, V.E. (2019). Upaya Penciptaan Iklim Investasi yang Kondusif. Info SIngkat. Badan Keahlian DPR RI. Vol. XI. No. 06.

Situmorang, M. (2015). Orientasi kebijakan politik luar negeri Indonesia di bawah pemerintahan Jokowi-JK. Jurnal Ilmiah Hubungan Internasional, 11(1).

Strauss, A., \& Corbin, J. (2008). Basics of Qualitative Research: Techniques and Procedures for Developing Grounded Theory (3rd Ed.). Thousand Oaks, London, New Delhi: SAGE Publications.

Supriatin (2019) Periode kedua, Menlu Retno akan perkuat Diplomasi Ekonomi Luar Negeri. Merdeka.com dalam https://www.merdeka.com/peristiwa/periode-kedua-menlu-retnoakan-perkuat-diplomasi-ekonomi-luar-negeri.html

Surya, A., \& Bukhari, A. S. (2019). PELUANG DAN TANTANGAN KERJASAMA INVESTASI INDONESIA DENGAN NEGARA-NEGARA VISEGRAD. Jurnal Ilmu Politik dan Komunikasi Volume IX No.

Walker, A. (April, 2020). Coronavirus: Drop in global trade to be worse than 2008 crisis. BBC.com. Retrieved from https://www.bbc.com/news/business-52211919

Weatherbee, D. E. (2017). Indonesia's foreign policy in 2016. Southeast Asian Affairs, 163-176. 